\title{
Nutrient Contents in Sugarcane Biomass in the First Regrowth Cycle
}

\author{
Vinicius S. G. da Silva ${ }^{1}$, Mauro W. de Oliveira ${ }^{1}$, Manoel G. Pereira ${ }^{2}$, Terezinha B. A. Oliveira ${ }^{1}$, \\ Carlos Henrique de C. Nogueira ${ }^{1}$, Fabiano da S. Brito ${ }^{1}$ \& Cicero L. Franco Jr. ${ }^{1}$ \\ ${ }^{1}$ Centro de Ciências Agrárias, Universidade Federal de Alagoas, Rio Largo, AL, Brazil \\ ${ }^{2}$ Departamento de Pesquisa e Desenvolvimento, Usina Triunfo, Boca da Mata, AL, Brazil \\ Correspondence: Vinicius S. G. da Silva, Centro de Ciências Agrárias, Universidade Federal de Alagoas, Rio \\ Largo, AL 51100-000, Brazil. Tel: 55-81-995-723-906. E-mail: vinicius.agro2008.1@gmail.com
}

Received: November 27, 2017

Accepted: January 3, 2018

Online Published: February 15, 2018

doi:10.5539/jas.v10n3p325

URL: https://doi.org/10.5539/jas.v10n3p325

\begin{abstract}
Sugarcane extracts and accumulates high amounts of soil nutrients, because it produces large amounts of biomass. Nutrient contents for varieties widely used in the past can be found in the literature, but there is little information on current cultivars. In view of these considerations, the study aimed to determine the nutrient concentration in the shoot biomass of sugarcane varieties in the first regrowth cycle. The study was conducted at a Latossolo Amarelo in Fazenda Jequiá, located in the state of Alagoas, Brazil. The experiment was a randomized block design with five replicates, consisting of four sugarcane varieties: SP813250, RB867515, RB92579 and VAT90212. At maturity of the first regrowth sugarcane, nitrogen (N), phosphorus (P), potassium (K), $\mathrm{Ca}$ (calcium), $\mathrm{Mg}$ (magnesium), $\mathrm{S}$ (sulfur), zinc $(\mathrm{Zn})$, iron (Fe), copper $(\mathrm{Cu})$, manganese $(\mathrm{Mn})$ and Boron (B) contents were determined. Varietal differences were found in nutrient contents. However, no variety showed higher concentration for all the elements. The varieties showed the following order of macronutrient concentrations: $\mathrm{K}>\mathrm{N}>\mathrm{Ca}>\mathrm{Mg}>\mathrm{S}>\mathrm{P}$. The average values were $0.47,0.08,0.66,0.15,0.13$ and $0.11 \mathrm{dag} \mathrm{kg}^{-1}$ of $\mathrm{N}, \mathrm{P}, \mathrm{K}, \mathrm{Ca}, \mathrm{Mg}$ and $\mathrm{S}$, respectively. Concentrations of 9.9, 98.7, 29.2, 1.9 and $4.4 \mathrm{mg} \mathrm{kg}^{-1}$ of $\mathrm{Zn}, \mathrm{Fe}, \mathrm{Mn}, \mathrm{Cu}$ and $\mathrm{B}$ were found for the micronutrients, respectively.
\end{abstract}

Keywords: nutritional efficiency, sugarcane agriculture, sugarcane industry, nutrient accumulation

\section{Introduction}

Sugarcane is one of the world's most prominent bioenergy crops, occupying an area of approximately 27 million hectares (Santos et al., 2016). There has been a global interest in the crop in recent years, because of the prospect for the production of biofuels, and its energy balance being potentially positive (Smeets et al., 2009; Losordo et al., 2016; Clemente et al., 2017). Despite the promising scenario, global yield is lower than $60 \mathrm{t} \mathrm{ha}^{-1}$, which is well below the biological potential of the crop (Landell \& Bressiani, 2008). The low yield is caused by inadequate fertilization in relation to the crop needs, among other factors (Sousa Junior et al., 2017).

Due to high biomass production, sugarcane extracts and accumulates high amounts of soil nutrients (Oliveira et al., 2010). In working with macronutrient extraction of variety CB41-76, Orlando Filho et al. (1980) found average values of 73, 30, 85, 49, 51 and $69 \mathrm{~kg} \mathrm{ha}^{-1}$ for N, P, K, Ca, Mg and S, respectively. Oliveira et al. (2007) reported that accumulations in the shoot biomass for a production of $100 \mathrm{t}$ of industrialized stalks are approximately 8.0, 3.0, 0.6, 0.4 and $0.3 \mathrm{~kg}$ for iron, manganese, zinc, copper and boron, respectively.

Considering that the extraction of soil nutrients by sugarcane is high, adequate fertilizer management is essential for the crop to reach high yields. Furthermore, fertilization represents a significant percentage of the production costs of sugarcane agriculture, thus it must follow strict criteria for optimization to obtain higher yield at lower cost (Silva et al., 2017a).

Studies conducted in Brazil have shown that the varieties may present differences in the absorption and concentration of nutrients (Franco et al., 2007; Oliveira et al., 2010). These variations are due to the morphological and physiological characteristics of the varieties, associated with uptake kinetics, including the nutrient uptake rate, the Michaelis-Menten constant and the minimum concentration, below which no net influx occurs (Malavolta et al., 1997; Marshner, 2012). A variety is considered efficient when it has good capacity in absorbing nutrients and using them in the production of biomass (Silva et al., 2017a). 
Although essential for the nutritional management of sugarcane, studies that have evaluated nutrient content in the biomass of sugarcane grown in Brazil are irregular, and the information available mostly refers to varieties that are no longer used (Oliveira et al., 2010). Thus, studies evaluating nutrient content are of great importance because they allow the selection of more efficient varieties, reducing production costs.

In view of this, the study aimed to evaluate the macronutrient contents in the shoot biomass of varieties RB92579, SP813250, RB867515 and VAT90212 in the first regrowth cycle.

\section{Material and Methods}

\subsection{Description of the Experimental Area}

The study was conducted in the field, between late 2009 and early 2011, in the city of Anadia-AL (9 $48^{\prime} 24^{\prime \prime}$ S, $\left.36^{\circ} 6^{\prime} 55^{\prime \prime} \mathrm{W}\right)$, located in the Zona da Mata de Alagoas, Brazil (Figure 1). The climate is tropical rainy with dry summers, according to Koppen classification. The average annual rainfall is 1,200 $\mathrm{mm}$ and the average temperature is $29^{\circ} \mathrm{C}$ (Silva et al., 2017a).

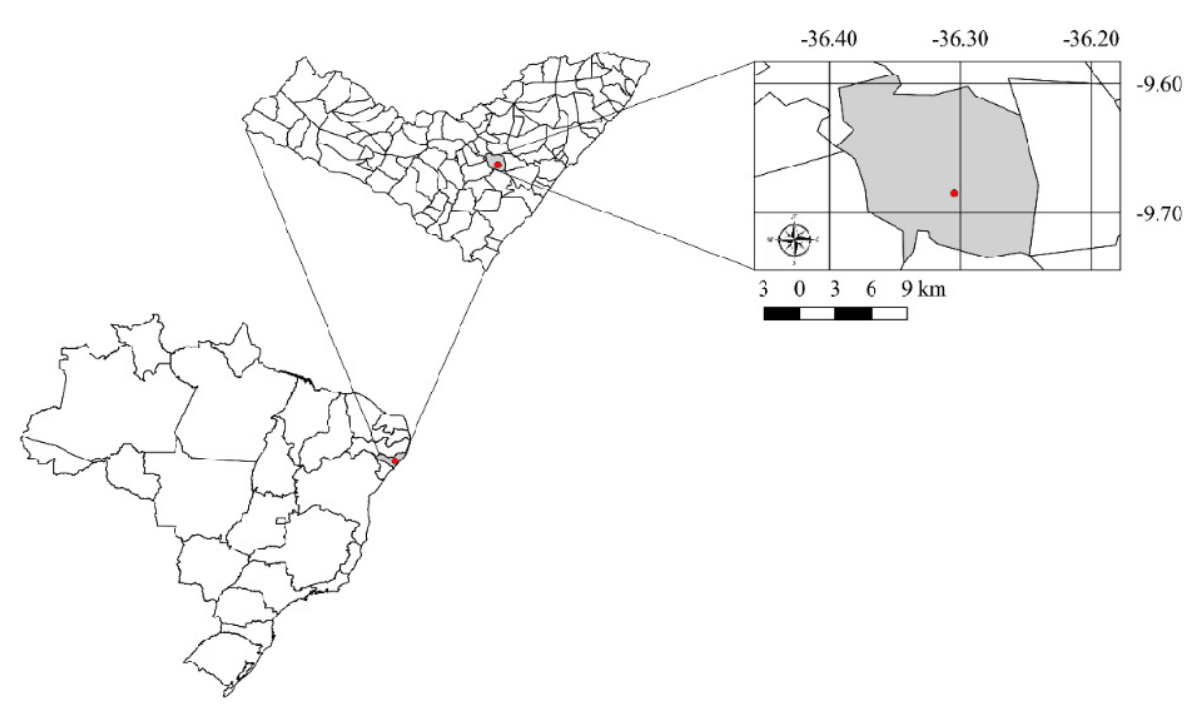

Figure 1. Location of the experimental area

The soil of the experimental area was classified as a Latossolo Amarelo (Embrapa, 2013). Prior to the commencement of the study, soil sampling was done at 0.0-0.2 and 0.2-0.4 $\mathrm{m}$ for chemical characterization (Table 1). The attributes evaluated in this study were $\mathrm{pH}\left(\mathrm{H}_{2} \mathrm{O}\right), \mathrm{Ca}^{2+}, \mathrm{Mg}^{2+}, \mathrm{K}^{+}, \mathrm{Al}^{3+},(\mathrm{H}+\mathrm{Al})$ and $\mathrm{P} \mathrm{Ca}^{2+}, \mathrm{Mg}^{2+}$ and $\mathrm{Al}^{3+}$ were extracted with $\mathrm{KCl} 1.0 \mathrm{~mol} \mathrm{~L}^{-1}$ and determined by titration. $\mathrm{P}$ and $\mathrm{K}$ were extracted using Mehlich-1. $\mathrm{P}$ was determined by colorimetry and $\mathrm{K}^{+}$by flame photometry. Potential acidity $(\mathrm{H}+\mathrm{Al}) \mathrm{was}$ extracted using $0.5 \mathrm{~mol} \mathrm{~L}^{-1}$ of calcium acetate and determined by titration. The analyses were done according to the methodologies described by Embrapa (2009).

Table 1. Soil chemical attributes of the experimental area at 0-20 $\mathrm{cm}$ and $20-40 \mathrm{~cm}$

\begin{tabular}{lllclccc}
\hline Layers & $\mathrm{pH}$ & $\mathrm{P}$ & $\mathrm{K}$ & $\mathrm{Ca}$ & $\mathrm{Mg}$ & $\mathrm{Al}$ & $\mathrm{H}+\mathrm{Al}$ \\
\hline$----\mathrm{cm}-----$ & $\mathrm{H}_{2} \mathrm{O}$ & ------ & $\mathrm{mg} \mathrm{dm}^{-3}------$ & ---------------- & cmolc dm $^{-3}$---------------- \\
$00-20$ & 5.9 & 103.0 & 40 & 1.8 & 0.8 & 0.0 & 3.80 \\
$20-40$ & 5.0 & 21.6 & 20 & 0.6 & 0.3 & 0.6 & 4.62 \\
\hline
\end{tabular}

\subsection{Soil Preparation and Planting of Sugarcane}

Based on the results of the soil analysis (Table 1), soil acidity was corrected using dolomitic limestone at a dose of $150 \mathrm{~kg} \mathrm{ha}^{-1}$, calculated by the method that aims to increase base saturation to $60 \%$, which is in line with Oliveira et al. (2007). After the application of limestone, the soil was plowed and harrowed, and finally the 
grooves were opened. The planting was done manually in September 2009. Sugarcane stalks with three buds per seed piece were distributed in the planting grooves in order to reach 18 buds per meter.

The evaluations were conducted in the first regrowth cycle. The cane-plant (2009-2010) lasted 16 months and the volume of rainfall in this period was $1873 \mathrm{~mm}$. The first regrowth (2010-2011) lasted 12 months, with rainfall of $1931 \mathrm{~mm}$ (Figure 2).

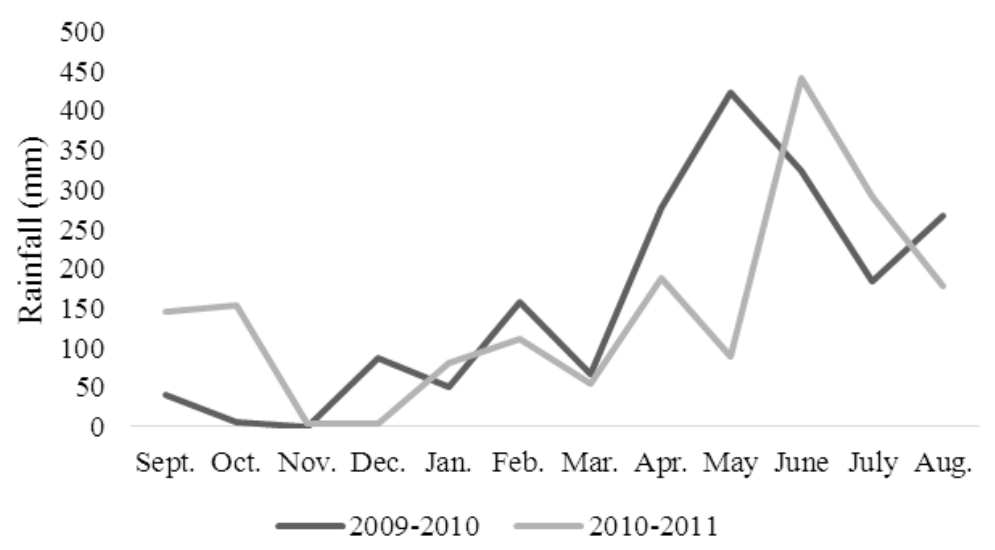

Figure 2. Monthly rainfall during the study period (Silva et al., 2017 a)

Fertilization was based on the recommendation of the Usina Triunfo, according to the results of the soil analysis (Table 1). Doses of 60,100 and $150 \mathrm{~kg} \mathrm{ha}^{-1}$ of N, $\mathrm{P}_{2} \mathrm{O}_{5}$ and $\mathrm{K}_{2} \mathrm{O}$ were applied to the bottom of the groove in the cane-plant cycle. At regrowth, the plots received $500 \mathrm{~kg} \mathrm{ha}^{-1}$ of the 20-05-25 formula (N-P-K).

\subsection{Experimental Design}

The study was conducted in a randomized complete block design with five replicates. The treatments consisted of four varieties of sugarcane: SP813250, RB867515, RB92579 and VAT90212. The cultivars were planted in plots with six grooves $\left(10.0 \mathrm{~m}\right.$ in length, $1.0 \mathrm{~m}$ apart), totaling $60 \mathrm{~m}^{2}$ of total area. The four central lines $(6.0 \mathrm{~m}$ in length) were considered the useful area of each plot, totaling $24 \mathrm{~m}^{2}$.

The varieties were chosen because of their high yield and industrial quality (Silva, 2017a, 2017b), in addition to the high representativeness. The sum of their cultivated areas was more than $50 \%$ of the area planted with sugarcane in the Northeast of Brazil, one year prior to the installation of the experiment.

\subsection{Evaluation of Nutrient Contents in Sugarcane Shoot Biomass}

At the time of maturation of the sugarcane (twelve months after the cutting of the cane-plant), the shoots of 10 plants were randomly sampled in the useful area of each plot. The sampled shoot was ground in a forage chopper, and then wet subsamples were collected. In the laboratory, the subsamples were dried in an oven at $65^{\circ} \mathrm{C}$ for 72 hours and weighed once again to determine the dry subsample. After obtaining the dry mass, the subsamples were ground in a Wiley-type mill. Shoot biomass was analyzed for nitrogen $(\mathrm{N})$, phosphorus $(\mathrm{P})$, potassium $(\mathrm{K})$, calcium (Ca), magnesium (Mg) and sulfur (S), following the methods described by Malavolta et al. (1997). N was extracted by sulfur digestion and determined by the Kjeldahl method, boron was extracted by dry digestion and determined by the Muffle furnace method, and the other nutrients were extracted by nitric-perchloric digestion. $\mathrm{P}$ was determined colorimetrically by the development of the blue color, by reducing the phosphomolybdate complex. K was determined by flame photometry. $\mathrm{Ca}, \mathrm{Mg}, \mathrm{Mn}, \mathrm{Fe}, \mathrm{Zn}, \mathrm{Cu}$ and $\mathrm{Fe}$ were determined by atomic absorption spectrophotometry and $\mathrm{S}$ by barium sulfate turbidimetry.

\subsection{Statistical Analysis}

The data were analyzed using Sisvar software (Ferreira, 2011). The variables were submitted to analysis of variance by the F-test and when significant, the means were compared by the Scott Knott test at 5\%.

\section{Results and Discussion}

The nitrogen contents in the shoot biomass of the sugarcane varieties RB867515, RB92579, VAT90212 and SP813250 are shown in Figure 1. RB867515 had the lowest concentration $\left(0.40 \mathrm{dag} \mathrm{kg}^{-1}\right)$. The other varieties did 
not differ from one another and presented an average of $0.48 \mathrm{dag} \mathrm{kg}^{-1}$. Calheiros et al. (2012) evaluated biomass, sugar and protein production in RB92579 and RB867515 and found an average $\mathrm{N}$ content of $0.49 \mathrm{~g} \mathrm{~kg}^{-1}$, which is similar to those found in this study.

Although Nitrogen constitutes less than $1 \mathrm{~g} \mathrm{~kg}^{-1}$ of plant biomass, it is essential to the growth and development of sugarcane as it participates in the formation of nucleic acids, amino acids, proteins, and hormones (Malavolta et al., 1997). Thus, the main biochemical reactions of sugarcane are dependent on $\mathrm{N}$, which is the element that sugarcane requires in larger quantities, after potassium (Oliveira et al., 2014; Ou et al., 2017). The effects of insufficient amounts of nitrogen on sugarcane growth were evaluated by Vale et al. (2011), who found reduction in growth, shoot and root biomass in plants grown under inadequate $\mathrm{N}$ supply.

VAT90212 had the highest concentration of $\mathrm{P}\left(0.106 \mathrm{dag} \mathrm{kg}^{-1}\right)$, approximately $30 \%$ higher than the content found in the other varieties (Figure 1). Oliveira et al. (2012) evaluated yield and quality of R867515 and RB92579 influenced by manganese and copper fertilization and found levels well below those of this study ( $0.106 \mathrm{dag}$ $\mathrm{kg}^{-1}$ ). This can be explained by the fact that the soil in this study had a high P content (average phosphorus values higher than $103 \mathrm{mg} \mathrm{dm}^{-3}$, extracted by Mehlich-1) (Table 1).

Various studies have shown that P the macronutrient least required by sugarcane (Benett et al., 2013; Rossato et al., 2016), although it is one of the elements that has most limited the cultivation of sugarcane in the tropics (Caione et al., 2013; Sousa et al., 2013; Simões Neto et al., 2015; Albuquerque et al., 2016). This fact is associated to the complex phosphorus dynamics in tropical soils, where there is predominance of 1:1 clays and iron and aluminum oxyhydroxides, which have high $\mathrm{P}$ adsorption capacity, promoting $\mathrm{P}$ fixation and reducing the efficiency of phosphate fertilization (Sanchez \& Uehara, 1980).

In plants, $\mathrm{P}$ participates both in the growth of the crop and in the production of sucrose. Additionally, $\mathrm{P}$ is highly important in most metabolic energy transfers. It acts as an intermediary in the synthesis of numerous complex molecules and it can regulate the rate of various enzymatic reactions and processes, such as respiration, glycolysis, photosynthesis, and in the synthesis and degradation of starch (Malavolta et al., 1997; Marschner, 2012). In addition to this metabolic importance, phosphorus exerts great influence on fermentation when the juice is used for the production of alcohol or cachaça, and in the processing and purification of the juice when it is intended for the manufacture of sugar. During the manufacture of sugar, the concentration of inorganic phosphorus (Pi) in the stalk influences the clearing of the juice. This is because Pi adsorbs several impurities contained within, and the compounds formed in this adsorption (being less soluble) precipitate, facilitating its separation from sucrose. According to César et al. (1987), phosphorus content should be higher than $100 \mathrm{mg}$ per liter of juice for good clearing. The organic phosphorus (Po) present in the sugarcane juice oscillates around 15\% and its concentration in the stalk varies less than Pi. However, Po is converted to Pi as the sugarcane matures.

No varietal effect was observed for potassium contents. The varieties had an average concentration of $0.66 \mathrm{dag}$ $\mathrm{kg}^{-1}$ (Figure 1). Studies have shown that potassium is the most extracted macronutrient by sugarcane (Coleti et al., 2006; Oliveira et al., 2007; Oliveira et al., 2014), and the high demand for this element is because it acts as an enzymatic activator, participating in many metabolic processes related to photosynthesis. In addition, it acts on the translocation of sucrose, either in the transport of the phloem, or in the cell-to-cell movement of sucrose towards the phloem, or of the phloem towards storage (Malavolta et al., 1997). 

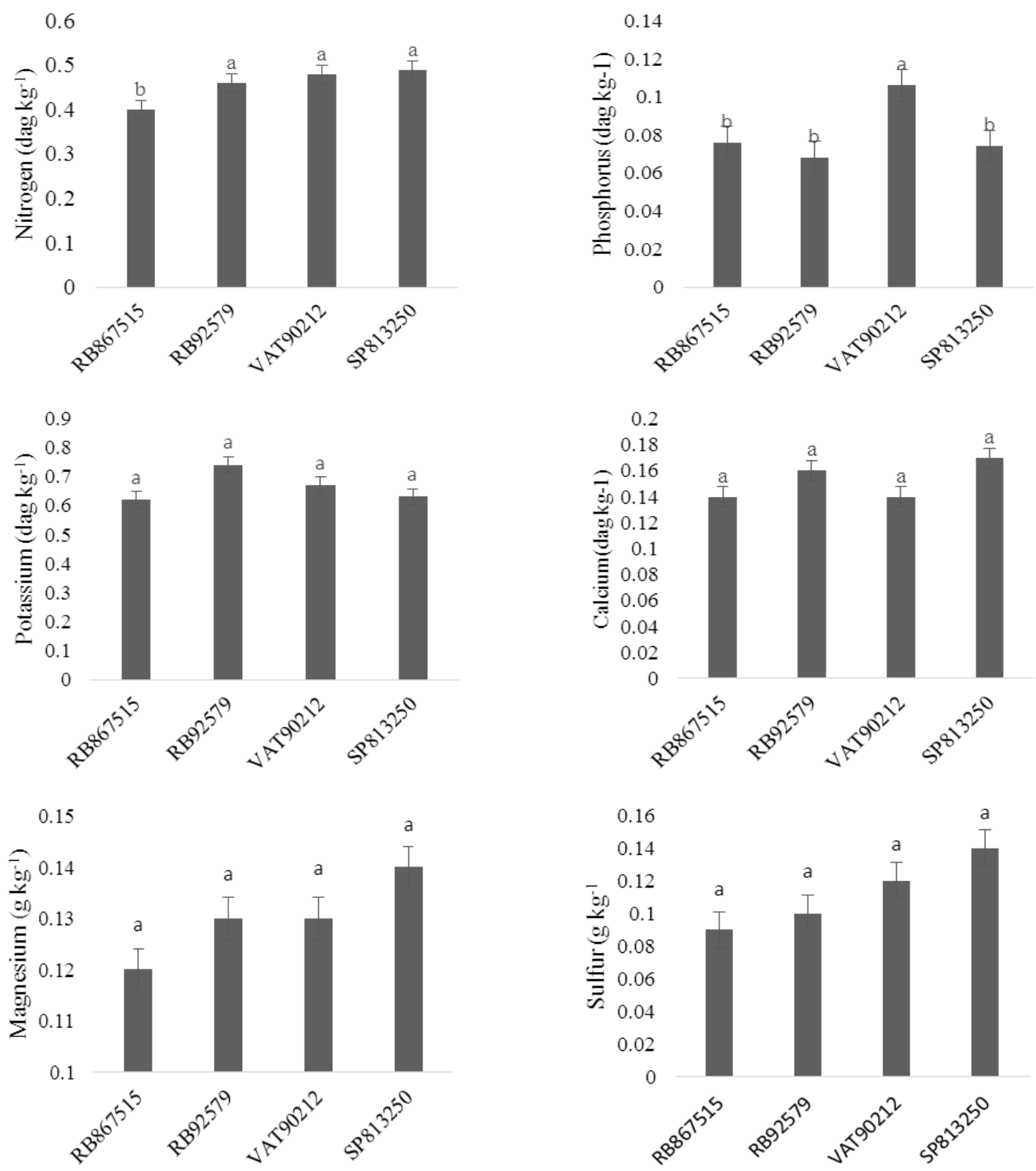

Figure 3. Macronutrient contents in the shoot biomass of four sugarcane varieties in the first regrowth cycle

Potassium also influences the industrial quality of the sugarcane, because when there is high P concentration in the plant, there is a delay in the maturation of sugarcane, proportionally increasing the content of reducing sugars (glucose and fructose) as well as ashes of the juice (Machado et al., 2003; Barker \& Davis, 2005). The increase in reducing sugars and potassium in the sugarcane juice is undesirable in the sugar production process, due to their melanogenic actions, which hinder the process of crystallization of sugar and decreases the purity of the sucrose (Vitti \& Maza, 2002; Machado et al., 2003). According to Casagrande et al. (1999), potassium concentration should be less than $2,000 \mathrm{mg}$ per liter of juice so that it does not interfere negatively in the crystallization process of the sucrose.

Ca contents were similar among the varieties and the plants presented $0.15 \mathrm{dag} \mathrm{kg}^{-1}$ on average (Figure 6). Romão et al. (2014) examined the chemical composition of variety 862480 treated with calcium oxide and found an average of $0.23 \mathrm{dag} \mathrm{kg}^{-1}$, compared to a biomass concentration of $0.14 \mathrm{dag} \mathrm{kg}^{-1}$ for the control treatment (without $\mathrm{CaO}$ ), both of which were similar to this study. Calcium is essential in the growth of sugarcane and this is evidenced by the high amounts extracted by the plants. According to Oliveira et al. (2010), 0.92 to $1.52 \mathrm{~kg} \mathrm{t}^{-1}$ of calcium are extracted in stalks. The high Ca requirement is due to its participation in the cell wall and it is 
important in the functioning of the intercellular membranes, which explains the coordination capacity of Ca, being a structural component in intermolecular bonds (Malavolta et al., 1997).

In regards to magnesium contents, an average concentration of $0.13 \mathrm{dag} \mathrm{kg}^{-1}$ was found. Domingues et al. (2014) studied the mineral composition of hydrolyzed sugarcane under virgin limestone application and found contents $50 \%$ higher than those in this study. In plants, magnesium has a multitude of functions, especially as an activator of enzymatic reactions. Among the reactions in which $\mathrm{Mg}$ participates are the transfer of phosphate or nucleotides (phosphatases, kinases, ATPases, synthetases, nucleotide transferases), carboxylic groups (carboxylases, decarboxylases) and dehydrogenase, mutase and lyase activators. Magnesium has a structural role as a component of the chlorophyll molecule. It is needed to maintain the integrity of the ribosomes and undoubtedly contributes to maintaining the structural stability of nucleic acids and membranes. Additionally, it influences the movement of carbohydrates to other parts of the plant and stimulates the uptake and transport of $\mathrm{P}$ within the plant.

The varieties did not differ in terms of sulfur content and presented an average concentration of $0.11 \mathrm{dag}^{\mathrm{kg}} \mathrm{k}^{-1}$ (Figure 1). Sulfur is an important element in the production of amino acids, proteins and chlorophyll, and a component of vitamins and certain plant hormones. It improves root growth, promoting vigor and robustness.

No varietal effect was observed for zinc, iron, copper and boron. The plants had an average concentration of 9.9, 98.7, 1.9 and $4.4 \mathrm{mg} \mathrm{kg}^{-1}$, respectively (Table 2). For manganese, RB867515 showed the lowest levels (20.8 mg $\mathrm{kg}^{-1}$ ), while the other cultivars were similar and presented an average of $32 \mathrm{mg} \mathrm{kg}^{-1}$. The average micronutrient contents presented the following order of concentration: $\mathrm{Fe}>\mathrm{Mn}>\mathrm{Zn}>\mathrm{B}>\mathrm{Cu}$. Our results are consistent with those of Oliveira et al. (2007) and Silva et al. (2017).

Table 1. Micronutrient contents in the shoot biomass of four sugarcane varieties

\begin{tabular}{llllll}
\hline Variety & Zn & Fe & Mn & Cu & B \\
\hline & $-0.8 \mathrm{a}$ & $81.6 \mathrm{a}$ & $31.0 \mathrm{a}$ & $1.8 \mathrm{a}$ & $3.8 \mathrm{a}$ \\
SP813250 & $12.0 \mathrm{a}$ & $90.4 \mathrm{a}$ & $34.6 \mathrm{a}$ & $2.4 \mathrm{a}$ & $5.0 \mathrm{a}$ \\
VAT90212 & $10.0 \mathrm{a}$ & $102.0 \mathrm{a}$ & $20.4 \mathrm{~b}$ & $1.8 \mathrm{a}$ & $4.0 \mathrm{a}$ \\
RB867515 & $7.8 \mathrm{a}$ & $120.0 \mathrm{a}$ & $30.8 \mathrm{a}$ & $1.6 \mathrm{a}$ & $4.8 \mathrm{a}$ \\
RB92579 & 9.9 & 98.7 & 29.2 & 1.90 & 4.42 \\
Average & 20.8 & 23.9 & 17.3 & 34.65 & 29.19 \\
CV (\%) & &
\end{tabular}

Note. Means followed by equal letters did not differ significantly from each other by the Scott Knott test $(\mathrm{p}<$ $0.05)$.

In most of the areas cultivated with sugarcane in Brazil, the soil provides adequate micronutrient supply. Thus, there is no need for addition via chemical fertilizers. However, the installation of sugarcane plantations in more sandy and less fertile or marginal soils in Alagoas and other Northeastern Brazilian states, combined with concentrated fertilization and planting of high-yield varieties (which progressively increase the absorption and export of nutrients) has caused micronutrient deficiency in several sugarcane plantations (Oliveira et al., 2007).

The varieties used in this study were the most planted in recent crops in Alagoas by large, medium and small producers, increasing the expansion area in the Northeast and South Central regions. These varieties have presented nutritional deficiency of copper and manganese, confirmed by studies on nutritional status (Oliveira et al., 2011; Silva et al., 2017), since $\mathrm{Cu}$ and $\mathrm{Mn}$ concentrations were below those considered minimum by Malavolta et al. (1997), and Raij (2011). In most of these crops, RB92579 had yield in excess of $80 \mathrm{t}$ of industrializable stalks per hectare, even expressing visual symptoms of deficiency. RB867515, which is a variety of high productive potential and heavily planted in the Northeastern and South Central regions, had leaf $\mathrm{Cu}$ and Mn contents below the minimum limits, even though it was not chlorotic.

A couple of the most cited functions for copper are oxidation and electron transfer. Several proteins containing copper play key roles in photosynthesis, respiration, superoxide radical detoxification and lignification. When there is copper deficiency, the activities of all these enzymes are drastically reduced. The decrease of electron transport in photosynthesis, as a consequence of the lower plastocyanin (a Cu-containing protein) content, decreases the amount of ATP and NADPH produced, reflecting on the $\mathrm{CO}_{2}$ fixation rate and the synthesis of sucrose and starch (Malavolta et al., 1997; Oliveira et al., 2007). 
Similar to copper, manganese participates in electron transfer. It is present in plants mainly in the divalent form (Mn II), only forming weaker bonds with organic ligands, in which Mn (III) and Mn (IV) can be readily oxidized. This ability to give and receive electrons causes manganese to function exclusively in the breaking of the water molecule and in the release of $\mathrm{O}_{2}$ (Kirkiby \& Römheld, 2007).

In addition to compromising the productive potential of these varieties, copper and manganese deficiency leads to metabolic changes that compromise juice quality, because these nutrients are constituents of metalloenzymes polyphenol oxidase and amylase (Malavolta et al., 1989; Marziah \& Lam, 1987; Robson et al., 1981). Therefore, there is accumulation of phenolic and starch compounds under poor performance of these enzymes.

\section{Conclusion}

In the first regrowth cycle, sugarcane varieties RB92579, SP813250, RB867515 and VAT90212 had the following decreasing order of macronutrient concentration in shoot biomass: $\mathrm{K}>\mathrm{N}>\mathrm{Ca}>\mathrm{Mg}>\mathrm{S}>\mathrm{P}$.

RB867515 presented the lowest concentration of nitrogen and manganese, while VAT90212 has the highest P content.

\section{References}

Benett, C. G. S., Buzetti, S., Silva, K. S., Teixeira Filho, M. C. M., Costa, N. R., Maeda, A. S., \& Andreotti, M. (2013). Quantidade de nutrientes na haste da cana-de-açúcar em função das fontes e doses de manganês. Semina: Ciências Agrárias, 34(3), 1077-1088. https://doi.org/10.5433/1679-0359.2013v34n3p1077

Caione, G., Fernandes, F. M., \& Lange, A. (2013). Efeito residual de fontes de fósforo nos atributos químicos do solo, nutrição e produtividade de biomassa da cana-de-açúcar. Revista Brasileira de Ciências Agrárias, 8(2), 189-196. https://doi.org//agraria.v8i2a2016

Calheiros, A. S., Oliveira, M. W., Ferreira, V. M., Barbosa, G. V. S., Santiago, A. D., \& Aristides, E. V. S. (2012). Production of biomass, from sugar and protein in function of sugarcane varieties and phosphorous fertilization. Semina: Ciências Agrárias, 33(2), 809-818. https://doi.org/10.5433/1679-0359.2012v33n2p80

Clemente, P. R., Bezerra, B. K. L., Silva, V. S. G., Santos, J. C. M., \& Endres, L. (2017). Root growth and yield of sugarcane as a function of increasing gypsum doses. Pesquisa Agropecuária Tropical, 47(1), 110-117. https://doi.org/10.1590/1983-40632016v4742563

Coleti, J. T., Casagrande, J. C., Stupiello, J. J., Ribeiro, L. D., \& Oliveira, G. R. (2006). Remoção de macronutrientes pela cana-planta e cana-soca, em Argissolo, variedades RB83486 e SP81-3250. STAB, 24, 32-36.

Domingues, F. N., Oliveira, M. D. S., Mota, D. A., Oliveira, R. P., Santos, J. D., Miranda, A. S., \& Godoy, B. S. (2014). Composição mineral da cana-de-açúcar in natura hidrolisada com cal virgem (CaO). Revista Brasileira de Saúde e Produção Animal, 15(4), 827-834. https://doi.org/10.1590/S1519-994020140 00400003

Embrapa (Empresa Brasileira de Pesquisa Agropecuária). (2009). Manual de análise química de solo, planta e fertilizantes (p. 627). Embrapa, Brasília.

Embrapa (Empresa Brasileira de Pesquisa Agropecuária). (2013). Sistema brasileiro de classificação de solos (p. 353). Embrapa, Brasília.

Ferreira, D. F. (2011). Sisvar: A computer statistical analysis system. Cienc Agrotec, 35(6), 1039-1042. https://doi.org/10.1590/S1413-70542011000600001

Franco, H. C. J., Bolonga, I. R., Faroni, C. E., Vitti, A., \& Trivelin, P. C. O. (2007). Acúmulo de macronutrientes em cana-de-açúcar em função da adubação nitrogenada e dos resíduos culturais incorporados ao solo no plantio. Bragantia, 66(4), 669-674. https://doi.org/10.1590/S0006-87052007000400017

Landell, M. G. A., \& Bressiani, J. A. (2008). Melhoramento genético e manejo varietal. In L. L. D. Miranda, A. C. M. Vasconcelos, \& M. G. A. Landell (Eds.), Cana-de-Açúcar (1st ed., pp. 101-156). Campinas: Instituto Agronômico de Campinas.

Losordo, Z., Mcbride, J., Rooyen, J. V., Wenger, K., Willies, D., Froehlich, A., \& Lynd, L. (2016). Cost competitive second-generation ethanol production from hemicellulose in a Brazilian sugarcane biorefinery. Biofuels, Bioproducts and Biorefining, 10 (5), 589-602. https://doi.org/10.1002/bbb.1663

Malavolta, E., Vitti, G. C., \& Oliveira, A. S. (1997). Avaliação do estado nutricional das plantas-Princípio e aplicações (p. 319). ABPPF, Piracicaba. 
Marschner, P. (2012). Mineral Nutrition of higher plants (3rd ed., p. 651). Elsevier, San Diego.

Oliveira, M. W., Freire, F. M., Macêdo, G. A. R., \& Ferreira, J. J. (2007). Nutrição mineral e adubação da cana-de-açúcar. Informe Agropecuário, 28(1), 30-43.

Oliveira, M. W., Silva, V. S. G., Oliveira, D. C., Silva, J. C. T., \& Reis, R. M. S. (2012). Production and forage quality of two sugarcane varieties affected by fertilization with copper and manganese. Revista Cientifica de Produção Animal, 14(2), 165-168. https://doi.org/10.15528/2176-4158/rcpa.v14n2p165-168

Oliveira, M. W., Silva, V. S. G., Reis, L. S., Oliveira, D. C., \& Silva, J. C. T. (2014). Produção e qualidade de três variedades de cana-de-açúcar cultivadas no Nordeste de Minas Gerais. Revista Ciência Agrícola, 12(1), 17-20.

Orlando Filho, J., Haag, H. P., \& Zambello Junior, E. (1980). Crescimento e absorção de macronutrientes pela cana-de-açúcar, variedade CB41-76, em função da idade, em solos do estado de São Paulo. Boletim Técnico PLANALSUCAR, 2 (p. 128). São Paulo, IAA.

Ou, H. P., Xie, R. L., Huang, J. S., \& Zeng, Y. (2017). Nutrients uptake and removal characteristics by high-yielding sugarcane grown in Guangxi, China. Research on Crops, 18(1), 170-175. https://doi.org/ $10.5958 / 2348-7542.2017 .00029 .8$

Romão, C. O., Carvalho, G. G. P., Leite, V. M., Santos, A. S., Chagas, D. M., Ribeiro, O. L., ... Pires, A. J. V. (2014). Chemical composition and dry matter digestibility of sugar cane oxide treated with calcium. Arquivo Brasileiro de Medicina Veterinária e Zootecnia, 66(2), 529-538. https://doi.org/10.1590/ 1678-41625930

Rossato, O. B., Crusciol, C. A. C., \& Martello, J. M. (2016). Fitomassa e acumulo de macronutrientes em cana-de-açúcar sob compactação e umidade do solo. Irriga, 21(3), 605-619. https://doi.org/10.15809/ irriga.2016v21n3p605-619

Sanchez, P. A., \& Uhera, G. (1980). Management considerations for acid soils with high phosphorus fixation capacity. In F. E. Khasawneh, E. C. Sample, \& E. J. Kamprath (Eds.), The role of phosphorus in agriculture (pp. 471-514). Madison: ASA; CSSA; SSSA.

Santos, L. A., Souza, J. E. A., Barboza, A. S. R., Silva, V. S. G., \& Clemente, P. R. A. (2016). Potencial energético da biomassa de cana-de-açúcar em uma usina sucroenergética. Revista da Universidade Vale do Rio Verde, 14(2), 1101-1108. https://doi.org/10.5892/ruvrd.v14i2.3027

Silva, V. S. G., de Oliveira, M. W., Oliveira, T. B. A., Mantovanelli, B. C., da Silva, A. C. I., Soares, A. N. R., \& Clemente, P. R. A. I. (2017). Leaf area of sugarcane varieties and their correlation with biomass productivity in three cycles. African Journal of Agricultural Research, 12(7), 459-466. https://doi.org/ 10.5897/AJAR2016.11817

Silva, V. S. G., Oliveira, M. W., Oliveira, D. C., Oliveira, T. B. A., Pereira, M. G., \& Nogueira, C. H. C. (2017a). Nutritional diagnosis of sugarcane varieties in a Yellow Oxisol during three agricultural seasons. Afr. $J$. Agric. Res., 12(1), 50-57. https://doi.org/10.5897/ AJAR2016.11865

Smeets, E. M. W., Bouwmanw, L. F., Stehfest, E. V., Vuuren, D. P., \& Posthuma, A. (2009). Contribution of $\mathrm{N}_{2} \mathrm{O}$ to the greenhouse gas balance of first generation biofuels. Global Change Biology, 15(1), 1-23. https://doi.org/10.1111/j.1365-2486.2008.01704.x

Sousa Junior, P. R., Brunharo, C. A., Furlani, C. E., Prado, R., Júnior, W. M., \& Zerbato, C. (2017). Phosphorus fertilization in sugarcane cultivation under different soil managements. Revista Brasileira de Engenharia Agricola e Ambiental-Agriambi, 21(10), 665-669. https://oi.org/10.1590/1807-1929/agriambi.v21n10 p665-669

Vale, D. W., Prado, R. M., Avalhães, C. C., \& Hojo, R. H. (2011). Omissão de macronutrientes na nutrição e no crescimento da cana-de-açúcar cultivada em solução nutritiva. Revista Brasileira de Ciências Agrárias, 6(2), 189-196. https://doi.org/10.5039/agraria.v6i2a550

\section{Copyrights}

Copyright for this article is retained by the author(s), with first publication rights granted to the journal.

This is an open-access article distributed under the terms and conditions of the Creative Commons Attribution license (http://creativecommons.org/licenses/by/4.0/). 